\title{
The master regulator for entry into sporulation in Bacillus subtilis becomes a cell-specific transcription factor after asymmetric division
}

\author{
Masaya Fujita and Richard Losick ${ }^{\mathbf{1}}$ \\ Department of Molecular and Cellular Biology, Harvard University, Cambridge, Massachusetts 02138, USA
}

Gene transcription at the onset of sporulation in Bacillus subtilis is governed by Spo0A, a member of the response regulator family of transcription factors. Spo0A is traditionally viewed as the master regulator for entry into development. We now report that Spo0A continues to function after the initiation phase of sporulation and that it becomes a cell-specific transcription factor when the sporangium is divided into a mother cell and forespore. We observed that (1) Spo0A and Spo0A-directed gene transcription reached high levels in the mother cell; (2) an activated form of Spo0A impaired sporulation when produced in the forespore but not when produced in the mother cell; and (3) an inhibitor of Spo0A called Spo0A-N impaired sporulation and Spo0A-directed transcription when produced in the mother cell but not when produced in the forespore. Spo0A-N, which corresponds to the $\mathrm{NH}_{2}$-terminal domain of Spo0A, was shown to compete with the full-length response regulator for phosphorylation by the phosphorelay protein Spo0B. We propose that Spo0A is the earliest-acting transcription factor in the mother-cell line of gene expression and that in terms of abundance and transcriptional activity Spo0A may function predominantly as a cell-specific regulatory protein.

[Keywords: Bacillus subtilis; sporulation; response regulator; transcription; asymmetry]

Supplemental material is available at http://www.genesdev.org.

Received January 28, 2003; revised version accepted March 5, 2003.

Sporulation in the bacterium Bacillus subtilis is governed by a series of transcription factors that are subject to temporal and spatial regulation (Stragier and Losick 1996; Piggot and Losick 2002). The initiation phase of development is controlled by Spo0A, which is traditionally considered to be the master regulator for entry into the sporulation pathway (Hoch 1993). Spo0A is a member of the response regulator family of transcription factors (Hoch 2000). The activity of Spo0A is determined by phosphorylation, which is mediated by a phosphorelay consisting of multiple kinases and two phosphorelay proteins, SpoOF and Spo0B (Burbulys et al. 1991). Environmental and physiological signals are integrated by the relay and by dedicated phosphatases that drain phosphoryl groups from it, to determine the phosphorylation state of Spo0A (Grossman 1995; Perego and Hoch 2002). Phosphorylated Spo0A (Spo0A P) sets up a self-reinforcing cycle that stimulates its own synthesis and phosphorylation (Predich et al. 1992; Strauch et al. 1993; Fu-

${ }^{1}$ Corresponding author.

E-MAIL losick@mcb.harvard.edu; FAX (617) 496-4642.

Article and publication are at http://www.genesdev.org/cgi/doi/10.1101/ gad.1078303. jita and Sadaie 1998). Spo0A P acts in conjunction with RNA polymerase containing the housekeeping sigma factor $\sigma^{\mathrm{A}}$ and with the alternative sigma factor $\sigma^{\mathrm{H}}$ to induce gene transcription at the start of sporulation (Stragier and Losick 1996; Piggot and Losick 2002). This transcription is responsible for remodeling the sister chromosomes of the developing cell (the sporangium) into an elongated nucleoid known as the axial filament (Pogliano et al. 2002; Ben-Yehuda et al. 2003) and for the formation of an asymmetrically positioned (polar) septum that divides the sporangium into unequal-sized compartments known as the forespore (the small compartment) and mother cell (Levin and Losick 1996; BenYehuda and Losick 2002). Spo0A P is also responsible for the synthesis and activation of the cell-specific regulatory proteins that set in motion the forespore and mother-cell lines of gene expression (Stragier and Losick 1996; Piggot and Losick 2002).

Here, we reexamine of the role of SpoOA in sporulation. We find that Spo0A continues to function after the initiation phase of sporulation. Our results indicate that Spo0A accumulates to high levels following the formation of the polar septum, when it is present principally or exclusively in the mother cell. Cells that have been en- 
gineered to produce an activated form of Spo0A in the forespore are impaired in sporulation. Likewise, cells that had been engineered to produce a newly devised inhibitor of Spo0A phosphorylation (called Spo0A-N) in the mother cell are defective in sporulation and in mother-cell-specific gene expression. Thus, Spo0A appears to have two distinct functions: as a master regulator during the initiation phase of sporulation and as a mother-cell-specific transcription factor following the formation of the polar septum. In terms of abundance and transcriptional activity, Spo0A may function predominantly as a cell-specific regulatory protein.

\section{Results}

Preferential transcription in the mother cell from promoters under the control of SpoOA

We previously presented evidence that transcription of the sporulation operon spoIIG persists after the morphological stage of polar division and that this transcription occurs preferentially in the mother cell compartment of the postdivisional sporangium (Fujita and Losick 2002). In comparison, a constitutively active promoter $P_{\text {spac }}{ }^{c}$ (which was derived from the IPTG-inducible $P_{\text {spac }}$ promoter by elimination of the operator for LacI repressor; Fujita and Losick 2002) directs the accumulation of green fluorescent protein (GFP) in both the forespore and mother-cell compartments of the postdivisional sporangium. $P_{\text {spoIIG }}$ and $P_{\text {spac }}{ }^{c}$ are transcribed by $\sigma^{\mathrm{A}}$-containing RNA polymerase, but transcription from $P_{\text {spoIIG }}$ is additionally dependent upon the phosphorylated form (Spo0A P) of Spo0A. Thus, it was conceivable that Spo0A acts preferentially in the mother cell. As a test of this idea, we fused $g f p$ to an additional sporulation promoter (that for the spoIIE operon) that is under the control of Spo0A P. As shown in Figure 1, GFP from the $P_{\text {spoIIE }}-g f p$ fusion as well as from a $P_{\text {spoIIG }}-g f p$ fusion preferentially accumulated in the mother-cell compart-

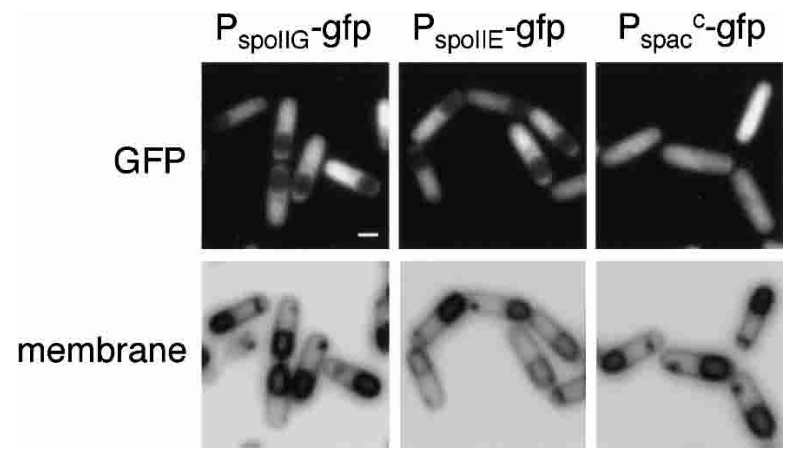

Figure 1. Subcellular localization of GFP produced under the control of Spo0A during sporulation. Strains carrying a $P_{\text {spoIIG }}{ }^{-}$ gfp fusion (MF237) or a $P_{\text {spoII- }}-g f p$ fusion (MF277) were induced to sporulate, treated with the vital membrane stain FM4-64 at hour 3 of sporulation, and observed by fluorescence microscopy. A strain carrying a $P_{\text {spac }}{ }^{c}-g f p$ fusion (MF339) was used as a control. Bar, $1 \mu \mathrm{m}$. ment of sporangia that had reached the stage of engulfment. In contrast, GFP from the $P_{\text {spac }}{ }^{c}-g f p$ construct was uniformly distributed throughout the sporangia. These findings are consistent with the idea that SpoOA remains active after polar division when it acts preferentially in the mother cell.

\section{Selective accumulation of SpoOA in the mother cell}

In light of the above results, we wondered whether Spo0A preferentially accumulates in the mother cell. To investigate this possibility, we carried out immunofluorescence microscopy using anti-SpoOA antibodies. Consistent with its being a DNA-binding protein, Spo0A was found to colocalize with the nucleoid. In predivisional sporangia and shortly after the formation of the polar septum, the sister chromosomes of the sporangium are in the form of an elongated, serpentine-like structure known as the axial filament. As sporulation progresses, the axial filament is resolved into separate mother cell and forespore nucleoids and the two nucleoids become compact (particularly so in the forespore) and amorphous.

Early after asymmetric division (hour 2), Spo0A was found in association with the axial filament in both chambers of the sporangium but generally appeared to be enriched in the mother cell. Over time, the abundance of Spo0A seemed to increase in the mother cell relative to the forespore, and by hour 4, little SpoOA could be detected in the forespore (Fig. 2; Supplementary Table 1). Instead, a strong signal from Spo0A was detected in the mother cell that colocalized with the mother-cell nucleoid. In comparison, the fluorescent signal obtained with antibodies against the major housekeeping sigma factor, $\sigma^{\mathrm{A}}$, was no less intense in the forespore than in the mother cell (Fig. 2; Supplementary Table 1).

These results suggest that Spo0A is a cell-specific transcription factor that selectively accumulates in the mother cell. Selective accumulation of SpoOA in the mother cell could be the result of persistent and selective synthesis of the regulatory protein in the mother cell or to degradation of Spo0A in the forespore, or both.

\section{Activation of SpoOA in the forespore inhibits sporulation}

As a test of the idea that Spo0A acts in a cell-specific manner after polar division, we investigated the effect of producing a constitutively active form of Spo0A in the forespore. Sad67 is a mutant form of Spo0A that is locked in an active state because of a short deletion internal to its coding sequence (Ireton et al. 1993). Sad67 does not depend on phosphorylation in order to be active. We placed the gene for Sad67 under the control of $P_{\text {spoIIQ }}$ the promoter for a sporulation gene (spoIIQ) that is transcribed in the forespore by $\sigma^{\mathrm{F}}$-containing RNA polymerase. The sporulation efficiency of the $P_{\text {spoIIQ }}$-sad67-containing strain (MF826) was 2\% that of the corresponding wild-type strain as judged by the production of heat-resistant, colony-forming units (spores) and by phase-con- 


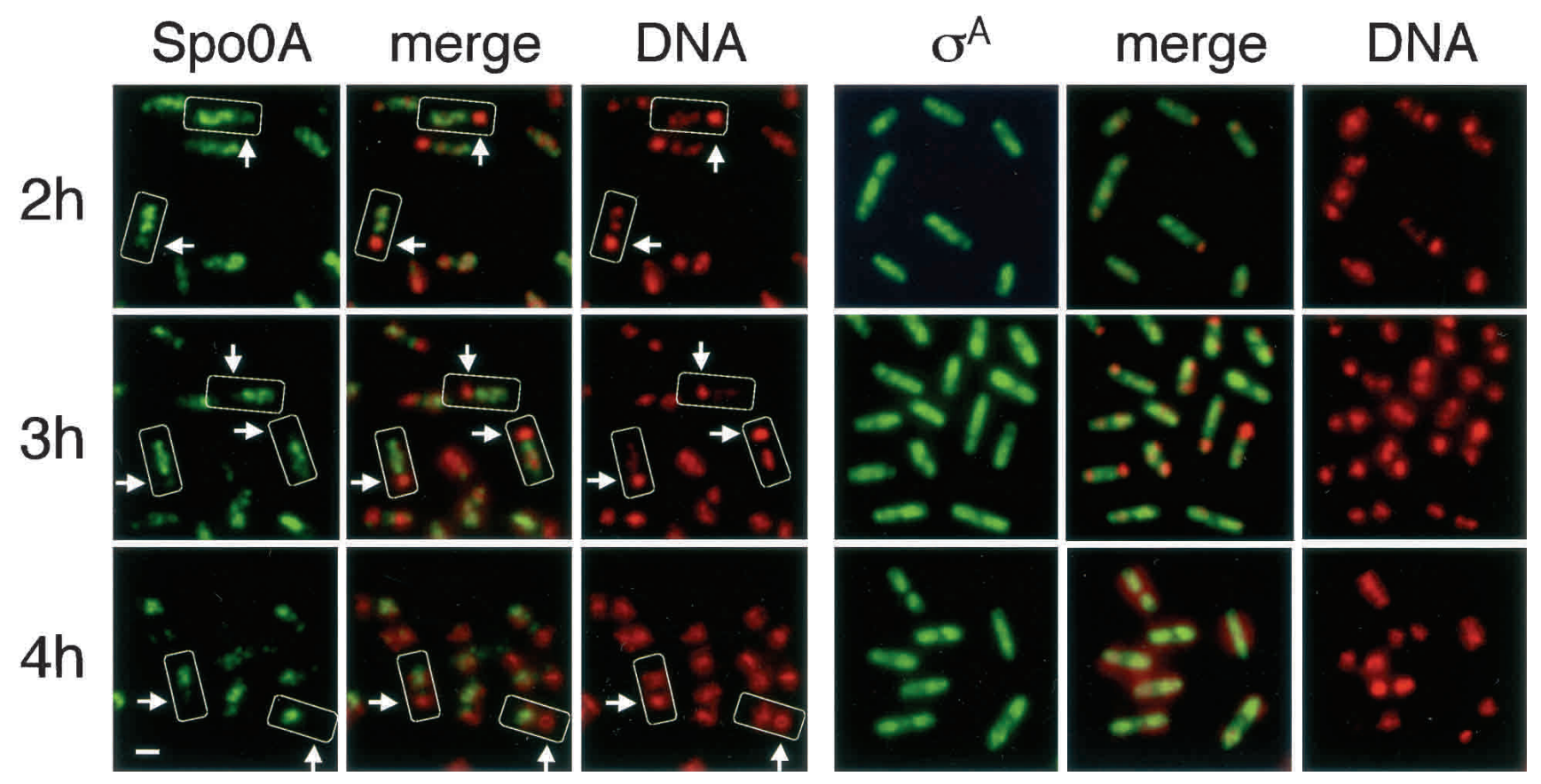

Figure 2. Subcellular localization of Spo0A. Sporulating cells of the wild-type strain PY79 were collected at the indicated times after the start of sporulation. Immunofluorescence microscopy was carried out using anti-Spo0A antibodies or, as a control, anti- $\sigma^{\mathrm{A}}$ antibodies and a secondary antibody conjugated to FITC (green). The cells were also stained with DAPI (red) to visualize DNA. Representative cells are highlighted by rectangles. Arrowheads point to the forespore. Bar, $1 \mu \mathrm{m}$.

trast microscopy (Fig. 3). That the impaired sporulation efficiency of MF826 was a result of the use of the sad67 allele was demonstrated by the construction of a strain (MF828) in which wild-type spo0A was placed under the control of $P_{\text {spoIIQ }}$. In contrast to MF826, MF828 was largely unimpaired in its ability to undergo sporulation. As a control, we constructed a strain (MF825) in which

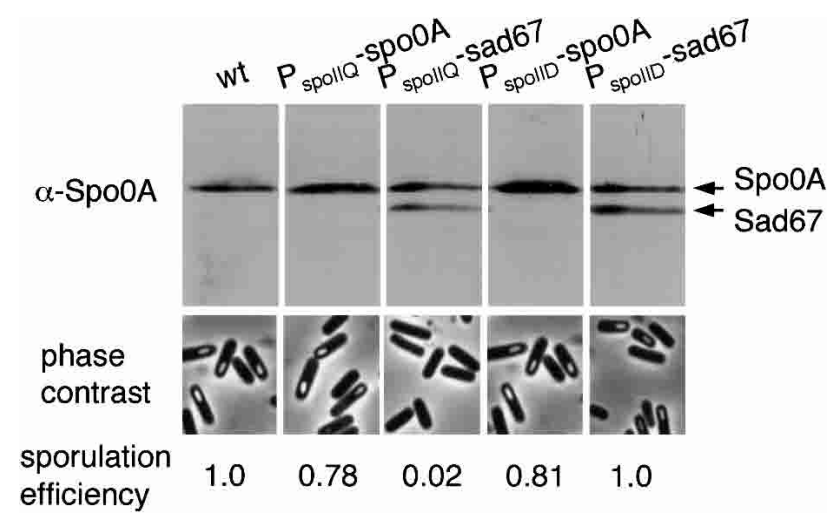

Figure 3. Artificial activation of Spo0A in the forespore inhibits sporulation. The strains used were: $\operatorname{MF} 825\left(P_{\text {spoIIQ }}-\right.$ Spo0A), MF826 ( $P_{\text {spoIIQ }}$-Sad67), MF827 ( $P_{\text {spoIID }}$-spo0A), and MF828 $\left(P_{\text {spoIID }}\right.$-sad67). Whole-cell extracts from cells collected at hour 3 of sporulation were subjected to SDS-PAGE and immunoblot analysis using anti-Spo0A antibodies (top panels). Cells were examined by phase-contrast microscopy at hour 4 of sporulation (bottom panels). Also shown are relative sporulation efficiencies for the strains. sad67 was under the control of the promoter for a gene (spoIID) that is transcribed in the mother cell by $\sigma^{\mathrm{E}}$ containing RNA polymerase. The sporulation efficiency of MF825 was similar from that of the wild type (Fig. 3). Finally, Western blot analysis carried out with antibodies against Spo0A showed that Sad67 (which can be distinguished from the wild-type protein by its smaller size) accumulated to similar levels in the $P_{\text {spoIIQ }}$-sad67-containing and the $P_{\text {spoIID }}$-sad67-containing strains. In toto, these findings indicate that Spo0A impairs sporulation when it is present and active in the forespore.

In other work, we sought to determine the stage of sporulation at which Sad67-producing sporangia become arrested. The results showed that cells of MF826 reached the stage of engulfment but were blocked in the expression of a gene $(\operatorname{spoIVB})$ under the control of the lateacting, forespore transcription factor $\sigma^{\mathrm{G}}$ but not in the expression of genes under the control of the earlier-acting regulatory proteins $\mathrm{SpoOA}, \sigma^{\mathrm{H}}, \sigma^{\mathrm{F}}$, and $\sigma^{\mathrm{E}}$ (data not shown).

Use of a truncated form of SpoOA to block activation of the full-length transcription factor

The results with Sad67 are consistent with the view that Spo0A is not normally active in the forespore. Next, we wished to address the complementary issue of whether Spo0A is not only active in the mother cell but also required in the mother cell for efficient sporulation. To address this issue, we took advantage of the fact that Spo0A, like other response-regulator proteins, consists of 
two domains: a receiver domain (the site of phosphorylation), which is located in the N-terminal portion of the protein, and a transcriptional regulatory (DNA-binding) domain, which is confined to the $\mathrm{C}$-terminal region (Hoch 2000). The receiver domain is phosphorylated by means of a phosphorelay involving multiple kinases and two phosphorelay proteins, SpoOF and SpoOB. SpoOF is responsible for transferring phosphoryl groups from the kinases to SpoOB, which, in turn, transfers the phosphoryl groups to Spo0A (Burbulys et al. 1991). We reasoned that a truncated form (Spo0A-N) of Spo0A corresponding to the N-terminal domain (residues 1-142) would compete with SpoOA for phosphorylation by the phosphorelay and hence impair activation of the full-length response regulator. Because sporulation is believed to depend on the attainment of a threshold level of SpoOA activity (Chung et al. 1994), we anticipated that even a modest level of competition might be enough to block sporulation.

As a test of our reasoning, we created a strain (MF972) harboring a fusion $\left(P_{\text {spoOA }}-s p o 0 A-N\right)$ of the coding sequence $(\operatorname{spo} 0 A-N)$ for Spo0A-N to the promoter for spo0A. MF972 produces both Spo0A-N and the full length SpoOA at the start of spourlation. The results of Figure 4A show that cells of MF972 were impaired in sporulation, exhibiting a block prior to polar septum formation.

Next, we carried out immunoblot analysis to determine the relative levels of SpoOA and SpoOA-N produced by MF972. A complication in this analysis was the likelihood that SpoOA-N, being a truncated form of Spo0A, would not be as immunoreactive as the full-length protein. Accordingly, we purified Spo0A and Spo0A-N and used the purified proteins to create standardized curves relating the intensity of the immunoblot signal to protein concentration. The results showed that SpoOA was approximately fivefold more immunoreactive than Spo0A-N on an equimolar basis (Fig. 4B). Using the standardized curves, we determined that SpoOA and Spo0A-N accumulated to similar levels in strain MF972, reaching concentrations of $\sim 200 \mathrm{fmole} / \mu \mathrm{g}$ of total cellular protein, which corresponds to $\sim 500$ molecules/cell.

\section{Overproduction of SpoOA suppresses the sporulation-inhibitory effect of SpoOA-N}

We interpret the results with MF972 to indicate that Spo0A-N competes with Spo0A for phosphorylation by the phosphorelay. If this interpretation is correct, then by artificially raising the concentration of SpoOA, we should be able to overcome the inhibitory effect of Spo0A-N and restore efficient sporulation. To test this prediction, we placed wild-type spoOA under the control of the IPTG-inducible promoter $P_{\text {spac }}^{I N}$. We then constructed a strain (MF1258) that harbored the IPTG-inducible $P_{\text {spac }}^{I N}-$ spoOA fusion and the $P_{\text {spooA }}-S p o O A-N$ fusion as well as a wild-type copy of spo0A. As shown in Table 1, MF1258 sporulated poorly in the absence of in-

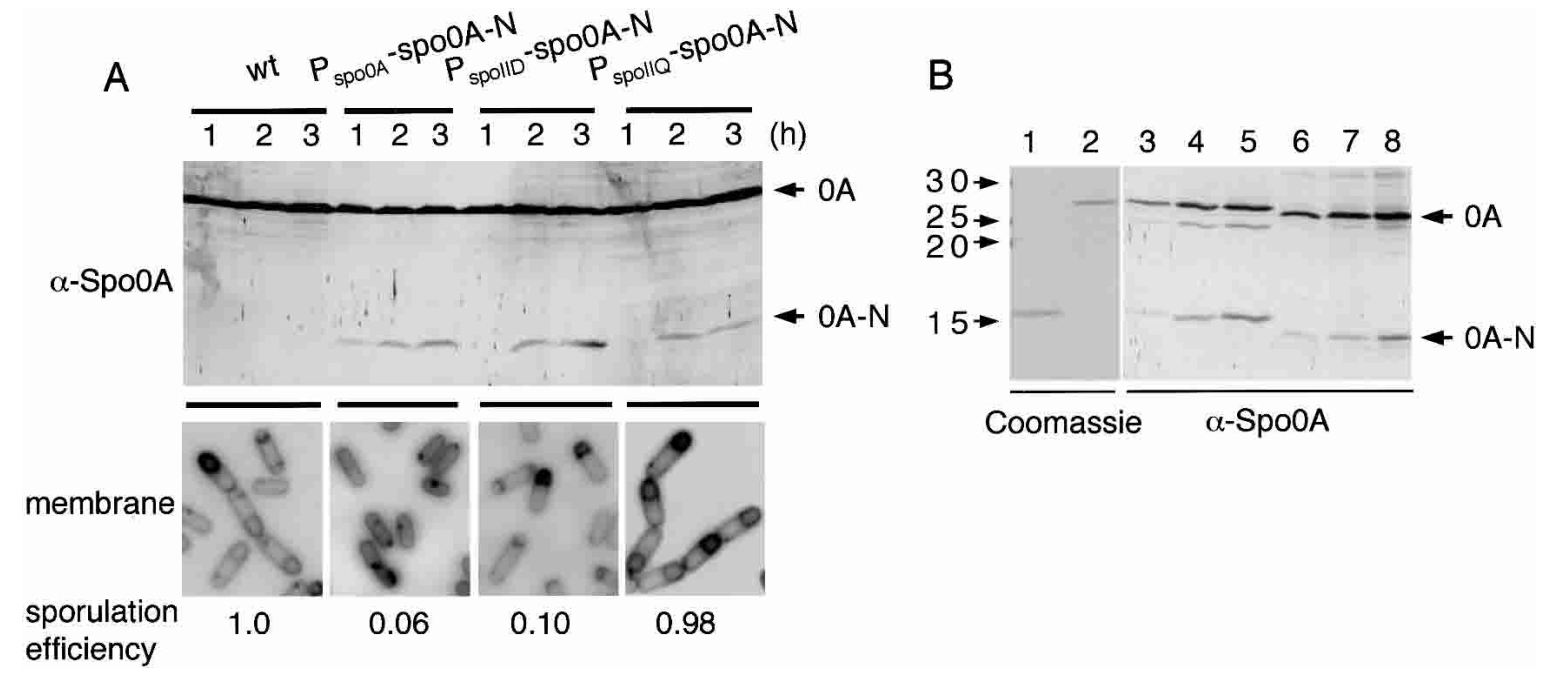

Figure 4. Inhibition of Spo0A activation in the mother cell inhibits sporulation. (A) Whole-cell extracts from cells of strain PY79 (wild type), MF972 ( $P_{\text {spooA }}-$ SpoOA-N), MF973 ( $P_{\text {spoIID }}-$ Spo0A-N), and MF974 ( $\left.P_{\text {spoIIQ }}-S p o 0 A-N\right)$ that had been collected at 1-h intervals after the start of sporulation were subjected to SDS-PAGE and immunoblot analysis using anti-Spo0A antibodies (top panel). Fluorescence microscopic images of cells that had been treated with FM4-64 at hour 4 of sporulation and sporulation efficiencies are shown for each of the strains (bottom panel). (B) Samples of purified SpoOA-His ${ }_{6}$ and SpoOA-N-His ${ }_{6}$ were subjected to SDS-PAGE and stained with Coomassie brilliant blue (lanes 1,2) or were subjected to SDS-PAGE and immunoblot analysis using anti-Spo0A antibodies (lanes 3-5). Samples of total protein from cells of strain MF972 collected at hour 2 of sporulation were subjected to SDS-PAGE and immunoblot analysis using anti-Spo0A antibodies (lanes 6-8). (Lane 1) Spo0A-N-His ${ }_{6}$ (14 pmole). (Lane 2) Spo0A-His ${ }_{6}$ (14 pmole). (Lane 3) Spo0A$\mathrm{His}_{6}+$ SpoOA-N-His $_{6}\left(0.035\right.$ pmole each). (Lane 4) SpoOA-His ${ }_{6}+$ SpoOA-N-His $_{6}(0.14$ pmole each). (Lane 5) Spo0A-His 6 + Spo0A-N-

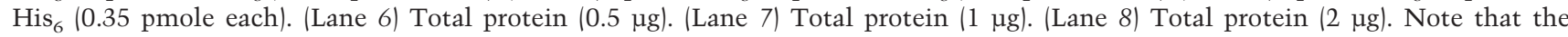
His-tagged proteins migrated slightly slower than the corresponding untagged proteins. Positions of molecular weight markers $(\mathrm{kD})$ are indicated on the left. 
ducer. However, the presence of IPTG enabled MF1258 to sporulate efficiently. This finding reinforces the view that the sporulation-inhibitory effect of SpoOA-N is a result of competition with the full-length regulatory protein.

\section{Spo0A-N competes with Spo0A for phosphorylation} by $\operatorname{SpoOB}$

To investigate the mechanism of action of Spo0A-N further, we asked whether or not purified Spo0A-N was capable of competing with the full-length protein for phosphorylation by phosphorelay proteins. Accordingly, we purified functional, tagged versions of Spo0A-N, KinA, SpoOF, SpoOB, and Spo0A (see Materials and Methods; see Supplemental Material), and reconstituted the phosphorelay in vitro (Fig. 5A, lanes 1-4). Similar to results obtained previously with a proteolytic fragment corresponding to the $\mathrm{NH}_{2}$-terminal portion of SpoOA (Grimsley et al. 1994), Spo0A-N was an effective substrate for phosphorylation by the phosphorelay (Fig. 5A, lane 5) and in a manner that was dependent upon the most downstream member of the phosphorelay, Spo0B (Burbulys et al. 1991). Importantly, in mixtures of the full length and truncated proteins, phosphorylation of Spo0A was partially inhibited by an equimolar amount of SpoOA-N and inhibited further as the concentration of Spo0A-N was raised (Fig. 5A, lane 6, 5B). At the same time, neither Spo0A-N nor Spo0A had a measurable effect on the level of phosphorylation of the phosphorelay protein SpoOF by the kinase KinA (Fig. 5A, lanes 2,7,8). Taken together, our results indicate that Spo0A-N is an effective and specific competitor of the phosphorylation of SpoOA by SpoOB P.

\section{Blocking SpoOA activation in the mother cell inhibits sporulation}

In toto, the above results indicate that Spo0A-N can be used as a specific inhibitor of SpoOA and that it does so by interfering with the phosphorylation of the fulllength protein. Finally, we wished to take advantage of this specific inhibitory effect to investigate whether or not sporulation depends on the continued activity of Spo0A in the mother cell. Accordingly, we constructed a strain in which a Spo0A-N was produced in the mother cell under the control the promoter for a gene (spoIID)

Table 1. Overproduction of SpoOA suppresses the sporulation defect of a strain producing SpoOA-N

\begin{tabular}{|c|c|c|c|}
\hline Strain & Induction & Spore/mL & $\begin{array}{c}\text { Sporulation } \\
\text { efficiency }\end{array}$ \\
\hline WT & & $5.0 \times 10^{8}$ & 1 \\
\hline${ }^{\mathrm{a}} \mathrm{P}_{\text {spooA-spoOA-N }}$ & & $2.0 \times 10^{7}$ & 0.04 \\
\hline $\begin{array}{c}{ }^{b} \mathrm{P}_{\text {spooA }}-\text { spo0A-N, } \\
\mathrm{P}_{\text {spac }} \text { IN }- \text {-spoOA }\end{array}$ & -IPTG & $5.5 \times 10^{7}$ & 0.11 \\
\hline $\begin{array}{c}{ }^{b} \mathrm{P}_{\text {spoOA }} \text {-spo0A-N, } \\
\mathrm{P}_{\text {spac }} \text { IN }_{\text {-spoOA }}\end{array}$ & +IPTG & $5.5 \times 10^{8}$ & 1.1 \\
\hline
\end{tabular}

that is transcribed by the mother-cell transcription factor $\sigma^{\mathrm{E}}$. The results of Figure 4A show that Spo0A-N impaired sporulation when the truncated protein was produced in the mother cell in a strain (MF973) harboring a fusion $\left(P_{\text {SpoIID }}-\right.$ SpoOA-N) of spoOA-N to the promoter for spoIID. As a control, production of Spo0A-N in the forespore under the control of the promoter for spoIIQ (strain MF974) caused little or no impairment of sporulation. Western blot analysis showed that Spo0A-N accumulated to similar levels when produced under the control of $\sigma^{\mathrm{F}}\left(P_{\text {spoIIQ }}-\right.$ SpoOA-N) or $\sigma^{\mathrm{E}}\left(P_{\text {spoIID }}-\right.$ SpoOA-N; Fig. 4A).

As an additional control, we investigated the effect of producing Spo0A-N under the control (using the promoter for the gerE gene) of a late-appearing transcription factor in the mother cell, $\sigma^{\mathrm{K}}$ (data not shown). The results showed that Spo0A-N impaired sporulation when produced at an early time in the mother-cell line of gene expression but not when produced at a late stage of development.

\section{Production of SpoOA-N in the mother cell inhibits SpoOA-dependent transcription from a mother-cell-expressed promoter}

If Spo0A-N in MF973 was acting by inhibiting the phosphorylation of Spo0A in the mother cell, then transcription from a promoter under the control of Spo0A should be impaired in the mother cell. As a test of this expectation, we used lac $Z$ fused to the promoter for an operon (spoIIG) that is under the control of SpoOA to monitor the effect of Spo0A-N on Spo0A-directed gene transcription (Fig. 6). When Spo0A-N was produced under the control of the $P_{\text {spoIID }}$ promoter (MF1151), accumulation of $\beta$-galactosidase from the $P_{\text {spoIIG }}-$ lac $Z$ fusion ceased at about hour 2 of sporulation, at a time approximately corresponding to when the polar division takes place and $\sigma^{\mathrm{E}}$ (and hence the $P_{\text {spoIID }}-$ SpoOA-N construct) is activated. For comparison, when Spo0A-N was produced under the control of the spoOA promoter (MF1140), accumulation of $\beta$-galactosidase was inhibited from the onset of sporulation. Furthermore, when Spo0A-N was produced in the forespore under the $P_{\text {spoIIQ }}$ promoter (MF1161), the pattern of $\beta$-galactosidase accumulation was indistinguishable from that of a strain (MF290) that did not produce Spo0A-N.

A complication in interpreting the results of Figure 6 is that $\beta$-galactosidase is unstable during sporulation. Hence the cessation of $\beta$-galactosidase accumulation seen at hour 2 in strain MF1151 is a composite of reduced transcription from $P_{\text {spoIIG }}-l a c Z$ as well as the degradation of $\beta$-galactosidase. We therefore interpret the results of Figure 6 to indicate Spo0A-N inhibited the transcription of $P_{\text {spoIIG }}-l a c Z$ in the mother cell, but did not necessarily block it altogether.

\section{Visualizing the effect of SpoOA-N on cell-specific gene expression}

To further analyze the effects of Spo0A-N on Spo0Adependent gene expression, we sought to monitor the 
A

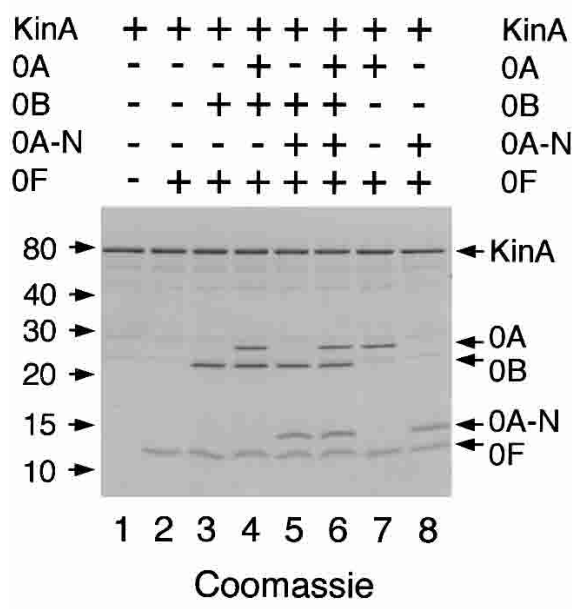

$\operatorname{KinA}+t+++++$

$--+-++$

$-++++-$

$---++-+$

$++t+t+$

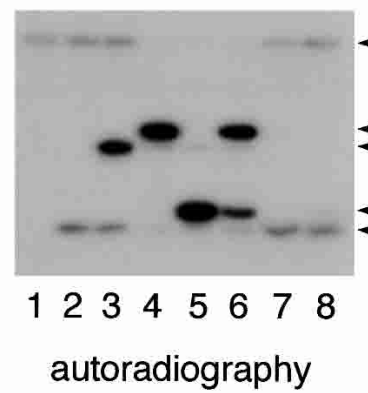

B

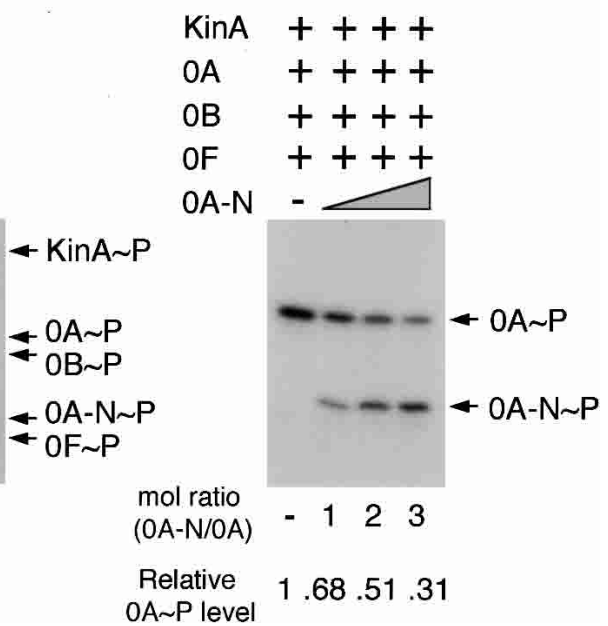

Figure 5. Spo0A-N competes with Spo0A for phosphorylation by phosphorelay proteins in vitro. Kinase reactions were performed as described in Materials and Methods, and the proteins were analyzed by SDS-PAGE. (A) Reaction mixtures $(20 \mu \mathrm{L})$ contained $0.2 \mu \mathrm{M}$ KinA (lanes 1-8), $0.2 \mu \mathrm{M}$ SpoOF (lanes 2-8), $0.2 \mu \mathrm{M}$ Spo0B (lanes 3-6), $2 \mu \mathrm{M}$ Spo0A (lanes 4,6,7), and $2 \mu \mathrm{M}$ Spo0A-N (lanes 5,6,8). Reaction mixtures were incubated at $25^{\circ} \mathrm{C}$ for $1 \mathrm{~h}$ and then stopped by adding SDS-loading buffer. Samples were subjected to electrophoresis through a $16 \%$ SDS-polyacrylamide gel, and radioactive proteins were visualized by autoradiography (right panel). Fourteen picomoles of each purified protein was subjected to electrophoresis and stained with Coomassie as a reference for electrophoretic mobility (left panel). (B) Reaction mixtures contained $0.2 \mu \mathrm{M}$ KinA, $0.2 \mu \mathrm{M}$ SpoOF, $0.2 \mu \mathrm{M}$ Spo0B, and $2 \mu \mathrm{M}$ Spo0A. Increasing amounts of SpoOA-N $(0,2,4$, and $6 \mu \mathrm{M}$, from left to right) were added to the reactions. The relative levels of Spo0A P are indicated.

influence of SpoOA-N on the spatial pattern of gene expression. To do this, we fused the coding sequence for the GFP to promoters under the control of SpoOA $\left(P_{\text {spoIIG }}\right), \sigma^{\mathrm{E}}\left(P_{\text {spoIID }}\right)$, and $\sigma^{\mathrm{F}}\left(P_{\text {spoIIQ; }}\right.$ Fig. 7$)$. Green fluorescence from the $P_{\text {spoIIG }}-g f p$ reporter construct in an

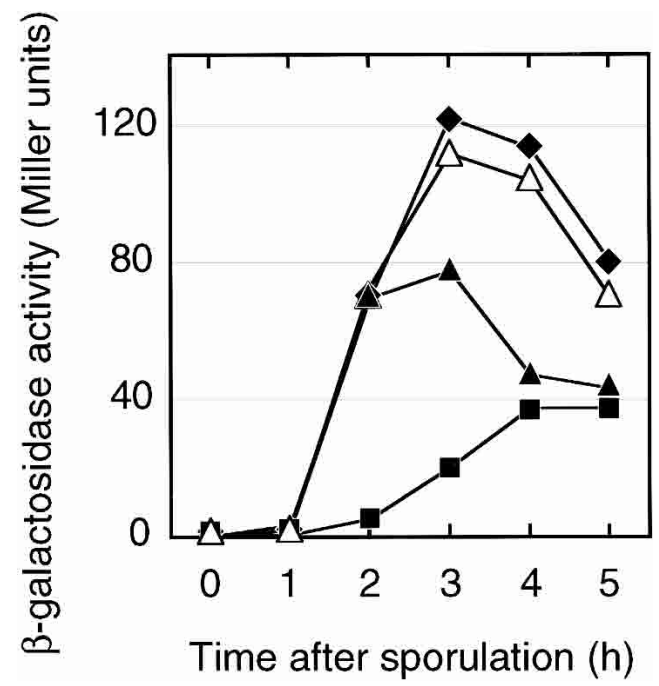

Figure 6. Inhibition of SpoOA activation inhibits expression of the spoIIG operon. Culture samples from strains MF290

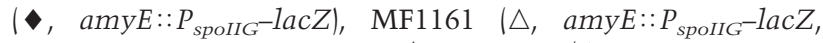

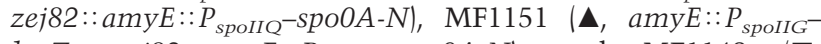
lacZ, zej82::amyE::P $P_{\text {spoIID }}-$ SpoOA-N), and MF1140 (ם, amyE $:: P_{\text {spoIIG }}-1 a c Z$, zej82::amyE $\left.:: P_{\text {spooA }}-S p o 0 A-N\right)$, were collected at 1 -h intervals after the start of sporulation and analyzed for $\beta$-galactosidase activity. otherwise wild-type strain (MF237) accumulated selectively in the mother cell after $3 \mathrm{~h}$ of sporulation. Meanwhile, GFP from the $P_{\text {spoIID }}-g f p$ (MF248) and $P_{\text {spoIIQ }}-g f p$ (PE128) reporter constructs was, as expected, restricted to the mother cell and forespore compartments, respectively of the postdivisional sporangia. (Notice that owing to the lipophilic nature of FM4-64, the membrane dye did not stain forespores in sporangia that had completed engulfment.)

Next, we created strains harboring the above described reporter constructs in combination with fusions of spo0A-N to the promoter for spo0A $\left(P_{\text {spooA }}-\right.$ SpoOA-N) and promoters under the control of $\sigma^{\mathrm{E}}\left(P_{\text {spoIID }}{ }^{-S p o 0 A-N)}\right.$ and $\sigma^{\mathrm{F}}\left(P_{\text {spoIIQ }}-\right.$ SpoOA-N). When Spo0A-N was produced from the $P_{\text {SpoOA }}-S p O 0 A-N$ fusion at the onset of sporulation, production of GFP from all three reporter constructs was significantly impaired and many of the sporangia failed to reach the stage of polar division. When Spo0A-N was produced in the mother cell from the $P_{\text {spoIID }}-$ SpoOA-N fusion, production of GFP from the Spo0A-dependent reporter $\left(P_{\text {spoIIG }}-g f p\right)$ was partially impaired (a minority of the sporangia exhibited significant levels of GFP in the mother cell) and production of GFP from the $\sigma^{\mathrm{E}}$-dependent reporter $\left(P_{\text {spoIID }}-g f p\right)$ was substantially impaired. In contrast, little or no impairment of $\sigma^{\mathrm{F}}$-directed synthesis of GFP in the forespore was observed in sporangia harboring the $P_{\text {spoIID }}$ spoOA-N fusion and no significant defect in polar division was detected. Finally, when SpoOA-N was produced in the forespore from the $P_{\text {spoIIQ }}-$ SpoOA- $N$ fusion, GFP accumulated normally from all three reporter constructs and no defect in polar division or engulfment was observed. 


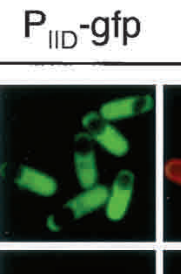

merge membrane
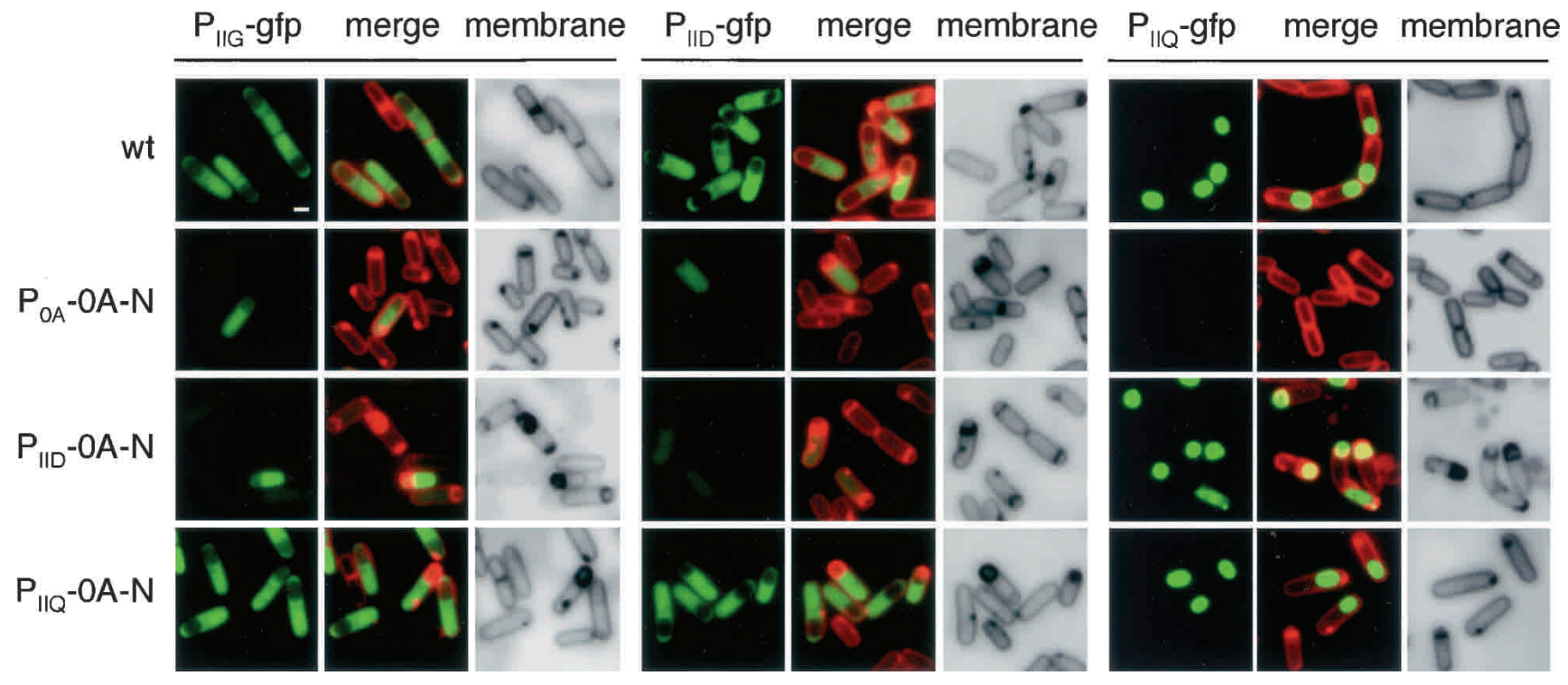

Figure 7. Subcellular localization of GFP synthesized under the control of Spo0A, $\sigma^{\mathrm{E}}$, or $\sigma^{\mathrm{F}}$ in the cells producing Spo0A-N. The strains used were MF237 ( $\left.P_{\text {spoIIG }}-g f p\right)$, MF1146 (P $P_{\text {spoIIG }}-g f p, P_{\text {spooA }}-$ Spo0A-N), MF1156 $\left(P_{\text {spoIIG }}-g f p, P_{\text {spoIID }}-\right.$ Spo0A-N), MF1166 $\left(P_{\text {spoIIG }}{ }^{-}\right.$ $g f p, P_{\text {spoIIQ }}-$ Spo0A-N), MF248 $\left(P_{\text {spoIID }}-g f p\right)$, MF1144 $\left(P_{\text {spoIID }}-g f p, P_{\text {spooA }}-s p o 0 A-N\right)$, MF1157 $\left(P_{\text {spoIID }}-g f p, P_{\text {spoIID }}-s p o 0 A-N\right)$, MF1167 $\left(P_{\text {spoIID }}-g f p, P_{\text {spoII }}-s p o 0 A-N\right), \operatorname{PE} 128\left(P_{\text {spoIIQ }}-g f p\right)$, MF1145 $\left(P_{\text {spoIIQ }}-g f p, P_{\text {spooA }}-\right.$ spo0A-N), MF1158 $\left(P_{\text {spoIIQ }}-g f p, P_{\text {spoIID }}-s p o 0 A-N\right)$, and MF1168 $\left(P_{\text {spoIIQ }}-g f p, P_{\text {spoIIQ }}-S p o 0 A-N\right)$. Cells were collected at hour 3 of sporulation, treated with the membrane strain FM4-64, and visualized by fluorescence microscopy. Bar, $1 \mu \mathrm{m}$.

\section{Discussion}

Spo0A has long been recognized as the master regulator for entry into sporulation (Burbulys et al. 1991; Hoch 1993). Mutants of the response regulator fail to undergo the hallmark morphological events (axial filament formation and polar division) characteristic of early development (Levin and Losick 1996; Ben-Yehuda and Losick 2002; Ben-Yehuda et al. 2003) or to switch on genes and operons (spoIIE, spoIIA, and spoIIG) that activate the forespore and mother-cell lines of gene expression (Stragier and Losick 1996; Piggot and Losick 2002). In modification of this traditional view, the results of the present investigation indicate (1) that Spo0A continues to function after the initiation phase of sporulation when it becomes a mother-cell-specific transcription factor, and (2) that its persistent and selective activity in the mother cell plays a critical role in development. Indeed, in terms of abundance and transcriptional activity, Spo0A arguably functions predominantly as a cell-specific regulatory protein.

These conclusions derive from the following observations. First, GFP produced under the control of two different Spo0A-controlled promoters continued to accumulate to high levels after asymmetric division and selectively in the mother cell. Second, Spo0A itself accumulated to high levels in the mother cell but not in the forespore. Third, an activated form of Spo0A (Sad67) impaired sporulation when it was produced in the forespore but not when it was produced in the mother cell. Finally, a newly devised, competitive inhibitor (Spo0A$\mathrm{N})$ of the phosphorylation of SpoOA impaired sporulation and mother-cell-specific gene expression when the in- hibitor was produced in the mother cell but not when it was produced in the forespore.

Additional evidence consistent with the view that Spo0A functions persistently during sporulation comes from studies with a heat-sensitive mutant of the response regulator. F. Kawamura (pers. comm.) has observed that the mutant remains sensitive to a shift to a restrictive temperature for several hours after the start of sporulation.

If, as we contend, the predominant role of SpoOA is as a cell-specific transcription factor, then what is the function of Spo0A in the mother cell? Part of the answer, we believe, involves the mother-cell regulatory protein $\sigma^{\mathrm{E}}$. The $\sigma^{\mathrm{E}}$ factor has traditionally been thought of as the earliest-acting regulatory protein in the mother-cell line of gene expression (Stragier and Losick 1996; Piggot and Losick 2002). It is derived by proteolytic processing from an inactive proprotein precursor, pro- $\sigma^{\mathrm{E}}$ (Stragier and Losick 1996; Piggot and Losick 2002). Both pro- $\sigma^{\mathrm{E}}$ and its processing enzyme, SpoIIGA, are encoded by the spoIIG operon (Jonas et al. 1988), which is under the direct control of Spo0A (Satola et al. 1992). As shown previously (Fujita and Losick 2002) and confirmed here, transcription of spoIIG largely takes place after the formation of the polar septum when it is confined to the mother cell. Also, as shown previously (Fujita and Losick 2002), $\sigma^{\mathrm{E}}$ and/or pro- $\sigma^{\mathrm{E}}$ accumulate to high levels after asymmetric division and selectively in the mother cell. These findings are now explained by the fact that Spo0A largely acts as a mother-cell-specific transcription. Meanwhile, processing of pro- $\sigma^{\mathrm{E}}$ is subject to an intercompartmental regulatory pathway involving the forespore transcription factor $\sigma^{\mathrm{F}}$ that ensures that pro- $\sigma^{\mathrm{E}}$ is not converted to 
mature $\sigma^{\mathrm{E}}$ until after the polar septum is formed (Stragier and Losick 1996; Piggot and Losick 2002). Thus, the relatively low level of pro- $\sigma^{\mathrm{E}}$ that is produced in the predivisional sporangium does not become active until after asymmetric division. Viewed in this light, the earliestacting, cell-specific transcription factor in the mothercell line of gene expression is Spo0A rather than $\sigma^{\mathrm{E}}$.

An implication of our findings is that the phosphorelay, which is responsible for phosphorylating Spo0A, also continues to function in the postdivisional sporangium. Indeed, the effectiveness of SpoOA-N in inhibiting Spo0A-directed gene transcription in the mother cell indicates that SpoOA function depends on its continued phosphorylation in the mother cell. The phosphorelay is generally believed to be a device for integrating environmental and physiological signals into the decision to sporulate, but the relay may also play a role in the conversion of Spo0A into a cell-specific transcription factor.

An important challenge for the future will be to elucidate the mechanisms that cause Spo0A to accumulate and function in a cell-specific manner. An appealing hypothesis is based on the phenomenon of transient exclusion. Formation of the polar septum initially traps the origin-proximal one third of the chromosome that is destined for the forespore in the small chamber of the sporangium. The remaining two thirds of the chromosome is subsequently pumped into the forespore across the polar septum by the DNA translocase SpoIIIE (Wu and Errington 1994). This results in a period of transient genetic asymmetry lasting for about $15 \mathrm{~min}$ when the forespore is lacking origin-distal genes and the mother cell temporarily contains an extra copy of these genes (Frandsen et al. 1999; Pogliano et al. 1999; Khvorova et al. 2000; Dworkin and Losick 2001; Zupancic et al. 2001). We note that the genes for all of the components of the phosphorelay, except SpoOF, are located outside the region of the chromosome that is initially trapped in the forespore (Stragier and Losick 1996). Thus, the temporary exclusion of phosphorelay genes from the forespore could set up an imbalance in which relay proteins are preferentially synthesized in the mother cell.

The effect of such an imbalance could be amplified by the following positive feedback loop. Spo0A P is known to stimulate the production of $\sigma^{\mathrm{H}}$ (through an indirect pathway involving the repressor AbrB), which, in turn, directly stimulates the transcription of the gene for Spo0A and the gene for KinA, the principal kinase for the phosphorelay (Predich et al. 1992; Fujita and Sadaie 1998). In addition, both Spo0A P and $\sigma^{\mathrm{H}}$ stimulate the transcription of the gene for the phosphotransferase protein SpoOF (Strauch et al. 1993; Fujita and Sadaie 1998). Such a selfreinforcing cycle would lead both to preferential synthesis of SpoOA and to preferential phosphorylation of the response regulator in the mother cell. Also contributing to the selective accumulation of SpoOA in the mother could be preferential degradation of the response regulator in the forespore. Conceivably, unphosphorylated Spo0A in the forespore is subject to proteolysis to a greater extent than is phosphorylated SpoOA in the mother cell.

In summary, Spo0A plays a dual role in sporulation, governing both the initiation phase of sporulation in the predivisional sporangium and acting as a cell-specific transcription factor in the postdivisional sporangium. Viewed in this light, Spo0A offers a striking parallel to the master regulator CtrA for the cell cycle in the dimorphic bacterium Caulobacter crescentus (Jensen et al. 2002; Shapiro et al. 2002). Like Spo0A, CtrA is a response regulator whose phosphorylation is believed to be governed by a phosphorelay (although this has not yet been demonstrated). Also, like Spo0A, CtrA functions both in the predivisional stage of the $C$. crescentus cell cycle as well as following division when it is restricted to only one (the swarmer cell) of the two resulting progeny cells. As more is learned about the compartmentalization of SpoOA, it will be interesting to compare and contrast the mechanisms by which Spo0A and CtrA come to act in a cell-specific manner.

\section{Materials and methods}

\section{General methods}

General methods were as previously described (Fujita and Losick 2002). All B. subtilis strains were derived from the prototrophic strain PY79 (Youngman et al. 1983) and are listed in Supplementary Table 1.

\section{Plasmid construction}

A complete description of the plasmids used can be found in Supplemental Material.

\section{Fluorescence microscopy}

Fluorescence microscopy was performed as described previously (Fujita and Losick 2002).

\section{Immunofluorescence microscopy}

Immunofluorescence microscopy was performed as described previously (Hofmeister 1998). The rabbit polyclonal antibodies that bind to $\sigma^{\mathrm{A}}$ and Spo0A (Fujita 2000) were used at 1:10,000 and 1:5000 dilutions, respectively.

\section{Immunoblot analysis}

Immunoblot analysis was done by the procedure of Rudner et al. (1999). Polyclonal anti-Spo0A antibodies were used for the detection of Spo0A (Fujita 2000).

\section{Protein expression and purification}

KinA, SpoOF, SpoOB, Spo0A, and Spo0A-N were produced as Cterminal $\mathrm{His}_{6}$ fusion proteins in Escherichia coli from plasmids pMF193 (see Supplemental Material), pGK10 (Burkholder et al. 2001), pMF184 (see Supplemental Material), pMF182 (modified version of pETSpo0A; Fujita and Sadaie 1998), and pMF182 (see Supplemental Material), respectively. Protein production was carried out in the E. coli BL21 (DE3) pLysS strains. Cells were grown in $\mathrm{LB}$ at $30^{\circ} \mathrm{C}$ to an $\mathrm{OD}_{600}$ of 0.6 , induced by addition of IPTG to $1 \mathrm{mM}$, and harvested after $5 \mathrm{~h}$. The proteins were purified by affinity chromatography on Ni-NTA agarose according to the manufacture's protocol (Qiagen). Protein concentrations were determined by Bradford assay (Pierce) using BSA as a standard.

\section{Phosphorylation reaction}

Phosphorylation reaction was done by the procedure of Burbulys et al. (1991). The reactions were initiated by addition of the ATP, stopped by addition of SDS-loading buffer, and immedi- 
ately loaded on a $16 \%$ SDS-polyacrylamide gel. Gels were exposed to X-ray film to detect phosphorylated proteins.

\section{Acknowledgments}

We thank J. Dworkin for providing strain JDB322; W.F. Burkholder for providing plasmid pGK10; S. Ben-Yehuda for help with immunofluorescence microscopy; and J. Dworkin, J.E. Gonzalez-Pastor, W. Haldenwang, F. Kawamura, and P. Piggot for helpful comments and discussions. M.F. was supported by a grant-in-aid for research abroad from the Ministry of Education, Culture, Sports, Science, and Technology, Japan. This work was supported by NIH grant GM18568 to R.L.

The publication costs of this article were defrayed in part by payment of page charges. This article must therefore be hereby marked "advertisement" in accordance with 18 USC section 1734 solely to indicate this fact.

\section{References}

Ben-Yehuda, S. and Losick, R. 2002. Asymmetric cell division in B. subtilis involves a spiral-like intermediate of the cytokinetic protein FtsZ. Cell 109: 257-266.

Ben-Yehuda, S., Rudner, D.Z., and Losick, R. 2003. RacA, a bacterial protein that anchors chromosomes to the cell poles. Science 299: 532-536.

Burbulys, D., Trach, K.A., and Hoch, J.A. 1991. Initiation of sporulation in $B$. subtilis is controlled by a multicomponent phosphorelay. Cell 64: 545-552.

Burkholder, W.F., Kurtser, I., and Grossman, A.D. 2001. Replication initiation proteins regulate a developmental checkpoint in Bacillus subtilis. Cell 104: 269-279.

Chung, J.D., Stephanopoulos, G., Ireton, K., and Grossman, A.D. 1994. Gene expression in single cells of Bacillus subtilis: Evidence that a threshold mechanism controls the initiation of sporulation. J. Bacteriol. 176: 1977-1984.

Dworkin, J. and Losick, R. 2001. Differential gene expression governed by chromosomal spatial asymmetry. Cell 107: 339-346.

Frandsen, N., Barak, I., Karmazyn-Campelli, C., and Stragier, P. 1999. Transient gene asymmetry during sporulation and establishment of cell specificity in Bacillus subtilis. Genes Dev. 13: 394-399.

Fujita, M. 2000. Temporal and selective association of multiple $\sigma$ factors with RNA polymerase during sporulation in Bacillus subtilis. Genes Cells 5: 79-88.

Fujita, M. and Losick, R. 2002. An investigation into the compartmentalization of the sporulation transcription factor $\sigma^{\mathrm{E}}$ in Bacillus subtilis. Mol. Microbiol. 43: 27-38.

Fujita, M. and Sadaie, Y. 1998. Feedback loops involving Spo0A and $\mathrm{AbrB}$ in in vitro transcription of the genes involved in the initiation of sporulation in Bacillus subtilis. J. Biochem. 124: 98-104.

Grimsley, J.K., Tjalkens, R.B., Strauch, M.A., Bird, T.H., Spiegelman, G.B., Hostomsky, Z., Whiteley, J.M., and Hoch, J.A. 1994. Subunit composition and domain structure of the Spo0A sporulation transcription factor of Bacillus subtilis. J. Biol. Chem. 269: 16977-16982.

Grossman, A.D. 1995. Genetic networks controlling the initiation of sporulation and the development of genetic competence in Bacillus subtilis. Annu. Rev. Genet. 29: 477-508.

Hoch, J.A. 1993. Regulation of the phosphorelay and the initiation of sporulation in Bacillus subtilis. Annu. Rev. Microbiol. 47: 441-465.

- 2000. Two-component and phosphorelay signal transduction. Curr. Opin. Microbiol. 3: 165-170.

Hofmeister, A. 1998. Activation of the proprotein transcription factor pro- $\sigma^{\mathrm{E}}$ is associated with its progression through three patterns of subcellular localization during sporulation in $\mathrm{Ba}$ cillus subtilis. J. Bacteriol. 180: 2426-2433.

Ireton, K., Rudner, D.Z., Siranosian, K.J., and Grossman, A.D. 1993. Integration of multiple developmental signals in Bacillus subtilis through the Spo0A transcription factor. Genes Dev. 7: 283-294.

Jensen, R.B., Wang, S.C., and Shapiro, L. 2002. Dynamic localization of proteins and DNA during a bacterial cell cycle. Nat. Rev. Mol. Cell Biol. 3: 167-176.

Jonas, R.M., Weaver, E.A., Kenney, T.J., Moran Jr., C.P., and Haldenwang, W.G. 1988. The Bacillus subtilis spoIIG operon encodes both $\sigma^{\mathrm{E}}$ and a gene necessary for $\sigma^{\mathrm{E}}$ activation. J. Bacteriol. 170: 507-511.

Khvorova, A., Chary, V.K., Hilbert, D.W., and Piggot, P.J. 2000. The chromosomal location of the Bacillus subtilis sporulation gene spoIIR is important for its function. J. Bacteriol. 182: 4425-4429.

Levin, P.A. and Losick, R. 1996. Transcription factor Spo0A switches the localization of the cell division protein FtsZ from a medial to a bipolar pattern in Bacillus subtilis. Genes Dev. 10: 478-488.

Perego, M. and Hoch, J.A. 2002. Two-component systems, phosphorelays, and regulation of their activities by phosphatases. In Bacillus subtilis and its closest relatives: From genes to cells (eds. A.L. Sonenshein, J.A. Hoch, and R. Losick), pp. 473 481. American Society for Microbiology, Washington, D.C.

Piggot, P.J. and Losick, R. 2002. Sporulation genes and intercompartmental regulation. In Bacillus subtilis and its closest relatives: From genes to cells (eds. A.L. Sonenshein, J.A. Hoch, and R. Losick), pp. 483-518. American Society for Microbiology, Washington, D.C.

Pogliano, J., Sharp, M.D., and Pogliano, K. 2002. Partitioning of chromosomal DNA during establishment of cellular asymmetry in Bacillus subtilis. J. Bacteriol. 184: 1743-1749.

Pogliano, J., Osborne, N., Sharp, M.D., Abanes-De Mello, A., Perez, A., Sun, Y.L., and Pogliano, K. 1999. A vital stain for studying membrane dynamics in bacteria: A novel mechanism controlling septation during Bacillus subtilis sporulation. Mol. Microbiol. 31: 1149-1159.

Predich, M., Nair, G., and Smith, I. 1992. Bacillus subtilis early sporulation genes kinA, spoOF, and spoOA are transcribed by the RNA polymerase containing $\sigma^{\mathrm{H}}$. J. Bacteriol. 174: 2771-2778.

Rudner, D.Z., Fawcett, P., and Losick, R. 1999. A family of membrane-embedded metalloproteases involved in regulated proteolysis of membrane-associated transcription factors. Proc. Natl. Acad. Sci. 96: 14765-14770.

Satola, S.W., Baldus, J.M., and Moran Jr., C.P. 1992. Binding of Spo0A stimulates spoIIG promoter activity in Bacillus subtilis. J. Bacteriol. 174: 1448-1453.

Shapiro, L., McAdams, H.H., and Losick, R. 2002. Generating and exploiting polarity in bacteria. Science 298: 1942-1946.

Stragier, P. and Losick, R. 1996. Molecular genetics of sporulation in Bacillus subtilis. Annu. Rev. Genet. 30: 297-341.

Strauch, M.A., Wu, J.-J., Jonas, R.H., and Hoch, J.A. 1993. A positive feedback loop controls transcription of the spoOF gene, a component of the sporulation phosphorelay in Bacillus subtilis. Mol. Microbiol. 7: 967-974.

Wu, L.-J. and Errington, J. 1994. Bacillus subtilis spoIIIE protein required for DNA segregation during asymmetric cell division. Science 264: 572-575.

Youngman, P.J., Perkins, J.B., and Losick, R. 1983. Genetic transposition and insertional mutagenesis in Bacillus subtilis with Streptococcus faecalis transposon Tn917. Proc. Natl. Acad. Sci. 80: 2305-2309.

Zupancic, M.L., Tran, H., and Hofmeister, A.E. 2001. Chromosomal organization governs the timing of cell type-specific gene expression required for spore formation in Bacillus subtilis. Mol. Microbiol. 39: 1471-1481. 


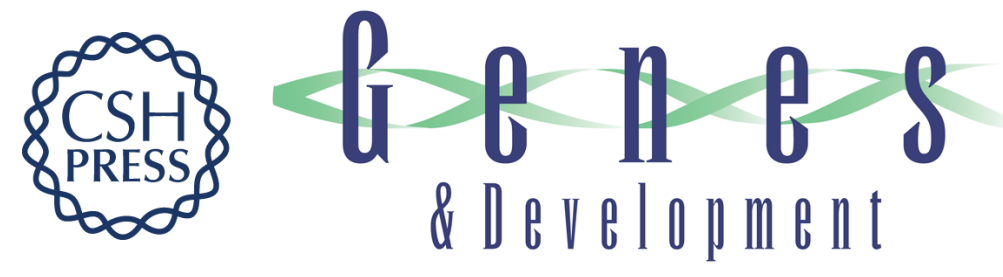

\section{The master regulator for entry into sporulation in Bacillus subtilis becomes a cell-specific transcription factor after asymmetric division}

Masaya Fujita and Richard Losick

Genes Dev. 2003, 17:

Access the most recent version at doi:10.1101/gad.1078303

Supplemental http://genesdev.cshlp.org/content/suppl/2003/05/04/17.9.1166.DC1
Material

References This article cites 31 articles, 16 of which can be accessed free at:

http://genesdev.cshlp.org/content/17/9/1166.full.html\#ref-list-1

License

Email Alerting Receive free email alerts when new articles cite this article - sign up in the box at the top

Service right corner of the article or click here.

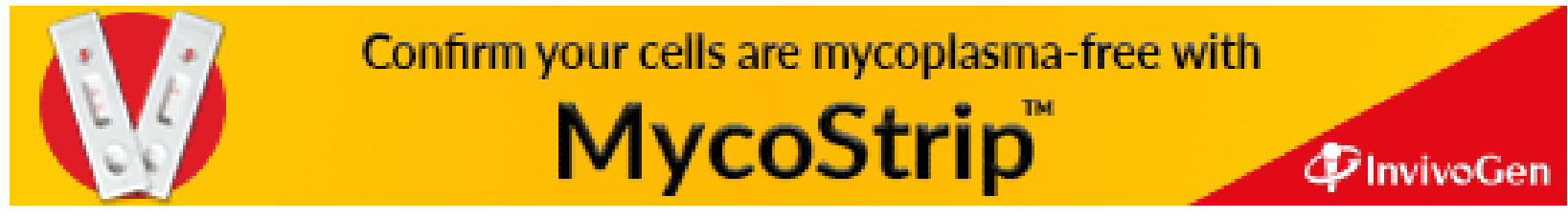

